University of Tennessee College of Law

Legal Scholarship Repository: A Service of the Joel A. Katz Law Library

2017

\title{
Artificial Intelligence \& Collusion: When Computers Inhibit Competition
}

\author{
Maurice Stucke \\ University of Tennessee College of Law \\ Ariel Ezrachi \\ University of Oxford
}

Follow this and additional works at: https://ir.law.utk.edu/utklaw_facpubs

\section{Recommended Citation}

Stucke, Maurice and Ezrachi, Ariel, "Artificial Intelligence \& Collusion: When Computers Inhibit Competition" (2017). UTK Law Faculty Publications. 128.

https://ir.law.utk.edu/utklaw_facpubs/128

This Article is brought to you for free and open access by the Faculty Work at Legal Scholarship Repository: A Service of the Joel A. Katz Law Library. It has been accepted for inclusion in UTK Law Faculty Publications by an authorized administrator of Legal Scholarship Repository: A Service of the Joel A. Katz Law Library. For more information, please contact eliza.boles@utk.edu. 


\title{
ARTIFICIAL INTELLIGENCE \& COLLUSION: WHEN COMPUTERS INHIBIT COMPETITION
}

\author{
Ariel Ezrachi* \\ Maurice E. Stucke*
}

The development of self-learning and independent computers has long captured our imagination. The HAL 9000 computer, in the 1968 film, 2001: A Space Odyssey, for example, assured, "I am putting myself to the fullest possible use, which is all I think that any conscious entity can ever hope to do." Machine learning raises many challenging legal and ethical questions as to the relationship between man and machine, humans' control-or lack of it-over machines, and accountability for machine activities.

While these issues have long captivated our interest, few would envision the day when these developments (and the legal and ethical challenges raised by them) would become an antitrust issue. Sophisticated computers are central to the competitiveness of present and future markets. With the accelerating development of $\Lambda I$, they are set to change the competitive landscape and the nature of competitive restraints. As pricing mechanisms shift to computer pricing algorithms, so too will the types of collusion. We are shifting from the world where executives expressly collude in smoke-filled hotel rooms to a world where pricing algorithms continually monitor and adjust to each other's prices and market data.

Our paper addresses these developments and considers the application of competition law to an advanced "computerised trade environment. "After discussing the way in which computerised technology is changing the competitive landscape, we explore four scenarios where AI can foster anticompetitive collusion and the legal and ethical challenges each scenario raises.

* Slaughter and May Professor of Competition Law, The University of Oxford; Director, Oxford University Centre for Competition Law and Policy.

** Professor, University of Tennessee College of Law; Co-founder, Data Competition Institute. We would like to thank for their helpful comments, the participants at the Oxford Uuiversity Centre for Competition Law and Policy's Round Table Discussion on Information Exchange and Market Transparency, Participants at the Bar Ilan University conference on Fairness in Antitrust, Greg Taylor and members of the Oxford Internet Institute. 


\section{TABLE OF CONTENTS}

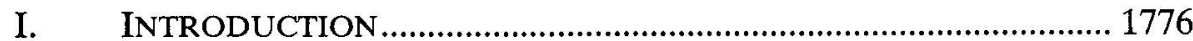

II. THE CHANGING COMPETITION LANDSCAPE ............................... 1778

III. THE SPECTRUM OF POSSIBLE ILLICIT CONDUCT ....................... 1781

A. First Category: The Computer as Messenger .......................... 1784

B. Second Category: Hub and Spoke ......................................... 1787

C. Third Category: Predictable Agent ....................................... 1789

1. Market Dynamics ........................................................... 1791

2. Enforcement Challenges ...................................................... 1793

D. Fourth Category: Digital Eye-Optimizing Performance... 1795

IV. REFLECTIONS AND POLICY CONSIDERATIONS............................. 1796

A. Determining the Primary Purpose for Increasing

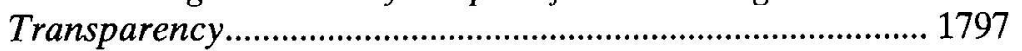

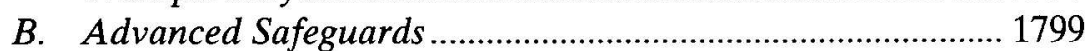

C. Injecting Uncertainty in a Certain World.............................. 1801

D. Reconsidering the Relationship Between Humans and Machines..

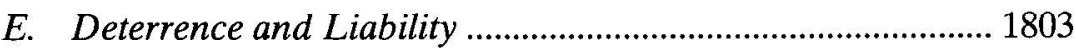

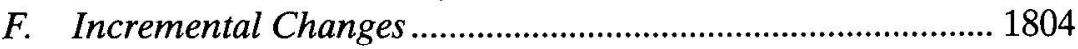

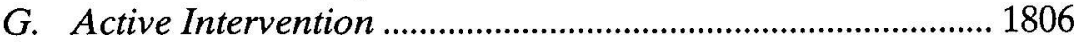

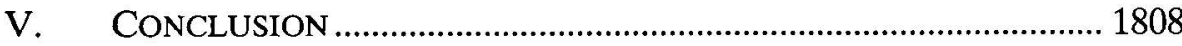

\section{INTRODUCTION}

"We will not tolerate anticompetitive conduct, whether it occurs in a smoke-filled room or over the Internet using complex pricing algorithms. American consumers have the right to a free and fair marketplace online, as well as in brick and mortar businesses."

The development of self-learning and independent computers has long captured our imagination. The HAL 9000 computer, in the 1968 film, 2001: A Space Odyssey, for example, assured, "I am putting myself to the fullest possible use, which is all I think that any conscious entity can ever hope to do." ${ }^{\prime 2}$ Today businesses (and governments) are increasingly relying on big data and big analytics. As technology advances and the cost of storing and analyzing data drops, companies are investing in developing "smart" and "self-learning" machines to assist in pricing decisions, planning, trade, and logistics. Furthermore, with the Internet of Things, more of our daily activities will be collected and used to enhance (or exploit) our immediate living environment-the way we commute,

1. Press Release, U.S. Dep't of Justice, Former E-Commerce Executive Charged with Pricc Fixing in the Antitrust Division's First Online Marketplace Prosecution (Apr. 6, 2015), https://www. justice.gov/opa/pr/former-e-commerce-executive-charged-price-fixing-antitrust-divisions-first-onlinemarketplace.

2. 2001: $\Lambda$ SPACE ODYSSEY (MGM 1968). 
shop, and communicate. ${ }^{3}$ These developments are accompanied by advances in Artificial Intelligence ("AI"). That is, the development of software and computers capable of self-learning and intelligent behavior."

Naturally, these devclopments raise many challenging legal and ethical questions as to the relationship between man and machine, humans' control-or lack of it-over machines, and accountability for machine activities. ${ }^{5}$ While these issues have long captivated our intercst, few would envision the day when these developments (and the legal and ethical challenges raised by them) would become an antitrust issue.

The antitrust community is accustomed to company executives fixing prices, allocating markets, and allocating bids. The film, The Informant!, captures these real-life executives who every year conspire around the world to fix prices and reduce output. ${ }^{6}$ Price-fixing cartels are generally regarded in the competition world as "no-brainers." The cartel agreement (even if unsuccessful) is typically condemned as per se illegal; the executives and companies have few, if any, legal defenses. ${ }^{7}$ And in the U.S., among other jurisdictions, the guilty executives are often thrown into prison. ${ }^{8}$

So it made the news when the U.S. Department of Justice ("DOJ") warned antitrust lawyers, economists, and scholars of the dangers of complex pricing algorithms. In 2015, the DOJ charged a price-fixing scheme involving posters sold through Amazon Marketplace. According to the DOJ, David Topkins and his coconspirators adopted specific pricing algorithms that collected competitor pricing information for specific posters sold online and applied the sellers' pricing rules. ${ }^{9}$ The competitors used the pricing algorithms with the goal of coordinating changes to their respective prices. ${ }^{10}$

Sophisticated computers are central to the competitiveness of present and future markets. With the accelerating development of AI, they are set to change the competitive landscape and the nature of competition restraints, which enforcement agencies will need to tackle. That notion was well reflected in the DOJ's criminal prosecution.

3. OVIDIU VERMESAN \& PETER Friess, INTERnEt of THINGS: CONVERgING TECHNOLOGIES FOR SMART ENVIRONMENTS AND INTEGRATED ECOSYSTFMS 37 (2013), http://www.internet-of-thingsresearch.eu/pdf/Converging_Technologies_for_Smart_Environments_and_Integrated_Ecosystems _IERC_Book_Open_Access_2013.pdf.

4. Artificial Intelligence, MERRIAM-WEBSTER, https://www.merriam-webster.com/dictionary/ artificial\%20intelligence (last visited Aug. 9, 2017).

5. See generally George F. Lugfer, Artificial INTElligence: STRUCtures AND Strategies for Complex Problem Solving 1 33, 821-53 (2005); John McCarthy \& Patrick J. Haycs, Some Philosophical Problems from the Standpoint of Artificial Intelligence, 4 MAcHINE INTELLIGENCE 1-51 (1969).

6. THE INFORMANT! (Warner Bros. Pictures 2009).

7. See Broadcast Music, Inc. v. Columbia Broadcasting System, Inc., 441 U.S. 1, 8-9 (1979).

8. See Criminal Program Update 2015, U.S. DEP'T OF JUSTICE, https://www.justice.gov/ atr/division-update/2015/criminal-program-update (last visited Aug. 9, 2017).

9. U.S. Dep't of Justice, supra note 1.

10. Id. 
With the present usage of computers and anticipated technological advancements, more industries will adopt sophisticated pricing algorithms and, as this Article discusses, there is a greater risk of sustainable tacit collusion. One may wonder: what is the role of competition law in this new environment of almost perfect price transparency and aligned incentives?

This Article addresses these developments and considers the application of competition law to an advanced "computerized trade environment." We believe that questions raised in these cases are central to our current thinking on antitrust enforcement and technological developments. Such questions concern, for example, the concept of agreement and intent in a computer-dominated environment, the boundaries of legality and collusion, the antitrust liability of algorithms' creators and users, the ability to constrain AI, the relationship between humans and computers, and the possibility of creating ethical, law-abiding machines.

After discussing in Part II the way in which computerized technology is changing the competitive landscape, Part III explores possible ways in which computers can foster collusion. We consider varying levels of technological development, which differ in the enforcement challenges they raise. Part IV reviews the competition policy challenges raised by advanced computers and AI. Part V concludes.

Our focus in this Article is predominantly on the implications of algorithmic collusion. Elsewhere, we discuss other aspects of the digital economy, including behavioral discrimination and super-platform competition. These themes are explored in our book, Virtual Competition: The Promise and Perils of the Algorithm-Driven Economy (Harvard University Press, 2016).

\section{The Changing Competition LANDSCAPE}

The increased automation of computerized protocols and the rapid developments in technology have changed the way we interact, communicate, and trade. Indeed, a look at the way in which we purchase goods and services reveals an increased reliance on the internet, computers, and technology. These processes have accelerated the relative decline of the high street trade and the rise of digitalized markets. ${ }^{11}$ They have affected our competitive landscape, as digitalized markets cover an ever increasing spectrum of commercial activities - from stock trading to the offer and purchase of online products and services. ${ }^{12}$

Indeed, with the rise of data-driven business models, companies are increasingly turning to computer algorithms that learn from the data they process. Such algorithms operate by "building a model from example inputs and using this to make predictions or decisions, rather than follow-

11. Globalization 101, Technology and Globalization 2 (2013), http:/www. globalization 101.org/uploads/File/Technology/tech.pdf.

12. Id. 
ing strictly static program instructions." 13 The velocity at which data are generated, accessed, processed, and analyzed has increased ${ }^{14}$ and, for some applications, is now approaching real-time.$^{15}$ Consequently, there is a "growing potential for big data analytics to have an immediate effect on a person's surrounding environment or decisions being made about his or her life." ${ }^{16}$ We see this with automated stock trading and other machine learning, where autonomous systems, through algorithms, can "learn from data of previous situations and to autonomously make decisions based on the analysis of these data."17

Interestingly, recent years have witnessed ground-breaking research and progress in the design and development of smart, self-learning machines. The field has attracted significant investment in deep-learning and AI by leading market players. ${ }^{18}$ In 2011, IBM's Jeopardy!-winning Watson computer showcased the power of computers and used deeplearning techniques, which enable the computer to optimize its strategy following trials and feedback..$^{19}$ Deep-learning techniques have also been implemented in day-to-day technology. For instance, the technology has been used by Microsoft in its Windows Phone and Bing voice search ${ }^{20}$ and by Audi in developing "driverless" cars. ${ }^{21}$ More recently, the launch of Deep Q-network by Google showcased enhanced self-learning capaci-

13. Sumit Mund, Microsoft AzUre MACHINe LeARNiNg 4 (2015).

14. MCKINSEy \& CU., Big DATA: THE NEXT FRONTIER FOR INNOVATION, COMPETTION, AND PRODUCTIVITY 98 (2011) ("More and more sensors are being embedded in physical devices-from assembly-line equipment to automobiles to mobile phones-that measure processes, the use of end products, and human behavior. Individual consumers, too, are creating and sharing a tremendous amount of data through blogging, status updates, and posting photos and videos. Much of these data can now be collected in real or near real time.").

15. John Podesta et al., Big Data: Seizing Opportunities, Preserving Values 5 (May 2014), https:/obamawhitehouse.archives.gov/sites/default/files/docs/big_data_privacy_report_5.1.14_ final_print.pdf.

16. Id. (giving examples of high-velocity data as "click-stream data that records users' online activities as they interact with web pages, GPS data from mobile devices that tracks location in real time, and social media that is shared broadly.").

17. ORGANISATION FOR ECONOMIC CO-OPERATION AND DEVELOPMENT, DATA-DRIVEN INNOVATION FOR GROWTH AND WELL-BEING 4 (Oct. 2014), https:/www.oecd.org/sti/inno/datadriven-innovation-interim-synthesis.pdf.

18. For example, on a year-over-year basis, funding for AI start-ups jumped more than $300 \%$. See Artificial Intelligence Startups See 302\% Funding Jump in 2014, CB INSIGHTS: BLOG (Feb. 10 , 2015), https://www chinsights.com/blog/artificial-intelligence-venture-capital-2014/. The most sizable deals included Sentient Technologies' $\$ 103.5 \mathrm{M}$ Series $\mathrm{C}$ financing from investors including Tata, Horizons Ventures, aud Access Industries and Vicarious Systems' \$40M Series B led by Formation 8. Id. ABB Technology Ventures later extended the round by another $\$ 12 \mathrm{M}$. Id.

19. Jo Best, IBM Watson: The Inside Story of How the Jeopardy-Winning Supercomputer Was Born, and What It Wants to Do Next, TECHREPUBLIC, http:/www.techrepublic.com/article/ibmwatson-the -inside-story of how-the-jeopardy-winning-supercomputer-was-born-and-what-it-wants-todo-nexu (last visited Aug. 9, 2017).

20. Kobert D. Hof, Deep Learning: With Massive Amounts of Computational Power, Machines Can Now Recognize Objects and Translate Speech in Real Time. Artificial Intelligence Is Finally Getting Smart, MIT TECH. REV., https:/www.technologyreview.com/s/513696/deep-learning/ (last visited Aug. 9, 2017).

21. David Talbot, CES 2075: Nvidia Demos a Car Computer Trained with "Deep Learning," MIT TECH. REV. (Jan. 6, 2015), https:/www.technologyreview.com/s/533936/ces-2015-nvidia-demos-a-carcomputer-trained-with-deep-learning/. 
ty. The computer was designed to play old fashioned Atari games. ${ }^{22}$ Importantly, it was not programmed to react to any possible move in the game; rather, it relied on models which enabled it to "learn" the game environment through trial and error and improve its performance over time. ${ }^{23}$ The technology mimics human learning by "changing the strength of simulated neural connections on the basis of experience. Google Brain, with about 1 million simulated neurons and 1 billion simulated connections, was ten times larger than any deep neural network before it." ${ }^{24}$

These technological developments - the rise of computerized market environments, accumulation and harvesting of data, automation of protocols, and machine learning - have far-reaching consequences when considered in the context of the nature and characteristics of competition between firms and their interface with consumers.

Take, for example, the way prices are determined. When we were growing up, humans monitored market activity and determined whether, and by how much, to raise or lower prices, and physically stamped products with price stickers. We recall the clerks along the supermarket aisle stamping each food can. Pricing decisions took weeks - if not months - to implement..$^{25}$ Now with online trading platforms, computers can assess and adjust prices-even for particular individuals at particular timeswithin milliseconds. ${ }^{26}$ Online trade platforms enable sellers to segment the market by using dynamic pricing. ${ }^{27}$ Pricing algorithms dominate online sales of goods-optimizing the price based on available stock and anticipated demand-and are widely used in hotel booking, and the travel, retail, sport, and entertainment industries. ${ }^{28}$ Such an algorithm, which Amazon used to optimize profitability, notably made headlines when it led to an unintended hike in the price of Peter Lawrence's book, The

22. Antonio Regalado, Is Google Cornering the Market on Deep Learning?, MIT TECH. REV. (Jan. 29, 2014), https://www.technologyreview.com/s/524026/is-google-cornering-the-market-on-deeplearning/.

23. Id.

24. See id.; Nicola Jones, Computer Science: The Learning Machines, NATURE (Jan. 8, 2014), http://www.nature.com/news/computer-science-the-learning-machines-1.14481.

25. Ariel Ezrachi \& Maurice E. Stucke, Virtual Competition: The Promise and PERILS OF THE ALGORITHM-DRIVEN ECONOMY 62 (2016).

26. Samuel B. Hwang \& Sungho Kim, Dynamic Pricing Algorithm for E-Commerce, in ADVANCES IN SYSTEMS, COMPUTING SCIENCES AND SOFTWARE ENGINEERING 149, 149-55 (Tarek Sobh \& Khaled Elleithy eds. 2006); Naoki Abe \& Tomonari Kamba, $A$ Web Marketing System with Automatic Pricing, 33 COMPUTER NETwORKS 775-88 (2000); Lusajo M. Minga et al., Dynamic Pricing: Ecommerce-Oriented Price Setting Algorithm, 2003 Proc. SeCond INT'L CONF. ON MACHINE LEARNING \& CYBERNETICS 893, 893.

27. See Salil K. Mehra, Antitrust and the Robo-Seller: Competition in the Time of Algorithms, 100 MiNN. L. REV. 1323, 1324 (2016) (discussing growth of pricing algorithms).

28. See About Us, REPRICER EXPRESS, https://www.repricerexpress.com/about-us/ (last visited Apr. 23, 2017); Competitor Price Tracker, PRISYNC, https://prisync.com/ (last visited Aug. 9, 2017); The Competitive Advantage for Retailers, BOOMERANG COM., http://www.boomerangcommerce.com/ (last visited Aug. 9, 2017). 
Making of a Fly. ${ }^{29}$ At its peak, the book was offered for sale at the price of $\$ 23,698,655.93$ (plus $\$ 3.99$ shipping). ${ }^{30}$

On the one hand, these increasingly automated, digitalized transactions could create a more transparent marketplace in which resources are allocated more efficiently and where the best product or service, at the lowest price, triumphs. On the other hand, these pricing algorithms raise "the seemingly endless possibilities for both chaos and mischief." 31

Alongside their pro-competitive promise, digitalized, algorithmbased markets are characterized by the ability of sellers to "shadow" the activities of users and harvest data on human behavior. ${ }^{32}$ The new market environment provides sophisticated players with the capacity to monitor customers' activities, accumulate data, and react to market changes with an ever-increasing speed. ${ }^{33}$ Computer algorithms may be used to optimize behavioral advertisements, individualized promotions, and targeted, discriminatory pricing. For example, Allstate used the so-called "marketplace considerations" algorithm, which sought to optimize pricing by determining the likelihood that users would compare prices before purchasing insurance. ${ }^{34}$ The use of the algorithm was criticized as it facilitated non-risk-based selective pricing which ranged from up to $90 \%$ discount off the standard rate to an increasing of premiums by up to $800 \% .^{35}$

\section{The SPECTRuM OF POSSIBLE IlLicit CONDUCT}

Competition enforcement typically focuses on possible illicit agreements among competitors, anticompetitive vertical restraints (such as resale price maintenance), the abuse of market power, and mergers that may substantially lessen competition. ${ }^{36}$ Our focus here is on collusion, which competition authorities across the world condemn. While antitrust enforcement predominantly targets corporations, the law considers the nature of illicit conduct through a "human" prism. ${ }^{37}$ Accordingly, the focal point for intervention is the presence of an agreement or understanding which reflects a concurrence of wills between the colluding compa-

29. Michael Eisen, Amazon's $\$ 23,698,655.93$ Book About Flies, IT Is NOT JUNK (Apr. 22, 2011), http://www.michaeleisen.org/blog/?p=358.

30. Andrew Couts, Why Did Amazon Charge $\$ 23,698,655.93$ for a Textbook?, DIGITAL TRENDS (Apr. 23, 2011, 11:58 AM), http://www.digitaltrends.com/computing/why-did-amazon-charge-2369 8655-93-for-a-textbook/.

31. See Eisen, supra note 29.

32. David J. Lynch, Policing the Digital Cartel, FIN. TIMES (Jan. 8, 2017), https://www.ft. $\mathrm{com} /$ content/9de9fb80-cd23-11e6-864f-20dcb35cede2?mhq5j=e4.

33. See id.

34. Don Jergler, Price Optimization Allegations Challenged, NAIC Investigating Practice, INs. J. (Dec. 18, 2014), http://www.insurancejournal.com/news/national/2014/12/18/350630.htm.

35. Press Release, Consumer Fed'n of Am., Media Access to Document Showing that Allstate Charges Illegal Rates Has Been Blocked (Dec. 17, 2014), http://consumerfed.org/press_release/mediaaccess-to-document-showing-that-allstate-charges-illegal-rates-has-been-blocked/.

36. The Antitrust Laws, FED. TRADE COMM'N, https:/www.ftc.gov/tips-advice/competitionguidance/guide-antitrust-laws/antitrust-laws (last visited Aug. 9, 2017).

37. Id. 
nies' agents.$^{38}$ Illegality is triggered when companies, through their directors, officers, employees, agents, or controlling shareholders, operate in concert to limit or distort competition. ${ }^{39}$

As illustrated above, we are shifting from the world where executives expressly collude in smoke-filled rooms to a world where pricing algorithms continually monitor and adjust to each other's prices and market data. In this new world, there is not necessarily any collusive agreement among executives. Each firm may unilaterally adopt its own pricing algorithm, which sets its own price. In this new world, there is not necessarily anticompetitive intent. The executives cannot predict if, when, and for how long the industry-wide use of pricing algorithms will lead to inflated prices. The danger here is not express collusion, but more elusive forms of collusion. Computers may limit competition not only through agreement or concerted practice, but also through more subtle means. For example, this may be the case when similar computer algorithms reduce or remove the degree of strategic uncertainty in the marketplace and promote a stable market environment in which they predict each other's reaction and dominant strategy. Such a digitalized environment may be more predictable and controllable. Furthermore, it does not suffer from behavioral biases and is less susceptive to possible deterrent effects generated through antitrust enforcement.

In what follows, we consider varying levels of technological development and use of computer algorithms, each raising different enforcement challenges. We identify four nonexclusive categories of collusionMessenger, Hub and Spoke, Predictable Agent, and Digital Eye. For each category, we consider the presence of two important legal concepts: (1) evidence of intent and horizontal agreement, and (2) potential liability.

The first category-Messenger-concerns the use of computers to execute the will of humans in their quest to collude and restrict competition. Under this basic scenario, humans agree to the cartel and use their computer to assist in implementing, monitoring, and policing the cartel. From an enforcement perspective, the legal concept of agreement can be applied straightforwardly, and prosecutors, with sufficient evidence, will have no difficulty condemning the use of machines to facilitate the cartel. Subsequently, intent evidence plays a limited role in this category.

The second category - Hub and Spoke-concerns the use of a single algorithm to determine the market price charged by numerous users. In this scenario, a single vertical agreement by itself may not necessarily generate anticompetitive effects and does not necessarily reflect an attcmpt to distort market prices. Yct, a cluster of similar vertical agreements with many of the industries' competitors may give rise to a classic hub-and-spoke conspiracy, whereby the developer (as the hub) helps orchestrate industry-wide collusion, leading to higher prices. ${ }^{40}$ Since evi-

\footnotetext{
38. See In re Text Messaging Antitrust Litigation, 630 F.3d 622, 628-29 (7th Cir. 2010).

39. See id.

40. See, e.g., JTC Petroleun Co. v. Piasa Molor Fuels, Inc., 190 F.3d 775, 778 (7th Cir. 1999).
} 
dence of the competitive effects of these vertical agreements may be mixed, intent evidence can help the competition officials to assess the agreement's purpose and likely competitive effects (i.e., did the companies agree to use the single algorithm to raise prices).

The third category-the Predictable Agent-presents a more complex scenario. Here, humans unilaterally design the machine to deliver predictable outcomes and react in a given way to changing market conditions. In this category, there is insufficient evidence of any agreement (either vertical or horizontal). Each operator is developing its machine unilaterally, with awareness of likely developments of other machines used by its competitors. ${ }^{41}$ In this case, an industry-wide adoption of similar algorithms may lead to anticompetitive effect through the creation of interdependent action. ${ }^{42}$ Crucially, the usc of advanced algorithms in this scenario transforms the market conditions. Before algorithms, transparency was limited and conscious parallelism could not be sustained. To facilitate the use of the price algorithms, the firms increase transparency, which makes the market more susceptible to tacit collusion/conscious parallelism in which prices will rise. Importantly, price increases in Category III are not the result of express collusion but rather the natural outcome of tacit collusion. ${ }^{43}$ While the latter is not itself illegal-as it conccrns rational reaction to market characteristics ${ }^{44}$ - one may ask whether its creation should give rise to antitrust intervention. Proof of intent to change market dynamics is central in this scenario.

The fourth category-Digital Eye-is the trickiest. Here, the competitors unilaterally create and use computer algorithms to achieve a given target, such as profit maximization. The machines, through selflearning and experiment, independently determine the means to optimize profit. ${ }^{45}$ Noticeably, under this category neither legal conceptintent nor agreement-apply. The computer executes whichever strategy it deems optimal, based on learning and ongoing feedback collected from

41. See, e.g., Dan Hill, The Secret of Airbnb's Pricing Algorithm, IEEE SPECTRUM (Aug. 20, 2015, 5:00 PM GMT), http://spectrum.ieee.org/computing/software/the-secret-of-airbnbs-pricingalgorithm

42. Scott S. Megregian et al., EU Commissioner Warns Companies of Potentially Unlawful Use of Pricing Algorithms, NAT'L L. REV. (Mar. 31, 2017), http://www.natlawreview.com/article/eucommissioner-warns-companies-potentially-unlawful-use-pricing-algorithms.

43. Conscious parallelism, also known as oligopolistic price coordination or tacit collusion, "describes the process, not in itself unlawful, by which firms" recognize their shared economic interests and their interdependence with respect to price and output decisions and then unilaterally set their prices above the competitive level. See Brooke Grp. v. Brown \& Williamson Tobacco Corp., 509 U.S. 209, 227 (1993); R. S. KHEMANI \& D. M. SHAPIRO, GLOSSARY OF INDUSTRIAL ORGANISATION ECONOMICS AND COMPETITION LAW 21 (1993), http://www.oecd.org/regreform/sectors/2376087.pdf.

44. Bell Atl. Corp. v. Twombly, 550 U.S. 544, 554 (2007) ("The inadequacy of showing parallel conduct or interdependence, without more, mirrors the ambiguity of the behavior: consistent with conspiracy, but just as much in line with a wide swath of rational and competitive business strategy unilaterally prompted by common perceptions of the market.").

45. Maurice E. Stucke \& Ariel Ezrachi, How Pricing Bots Could Form Cartels and Make Things More Expensive, HARV. BUS. REV. (Oct. 27, 2016), https://hbr.org/2016/10/how-pricing-bots-couldform-cartels-and-make-things-more-expensive. 
the market. Issues of liability, as we will discuss, raise challenging legal and ethical issues.

Before elaborating on each of the categories, the following table summarizes their key distinctions:

TABLE 1

\begin{tabular}{|c|c|c|c|}
\hline Category 1 : & $\begin{array}{l}\text { Apreement } \\
\text { Strong }\end{array}$ & $\begin{array}{l}\text { Intent } \\
\text { Limited role }\end{array}$ & $\begin{array}{l}\text { Elability } \\
\text { Per Se Illegal }\end{array}$ \\
\hline Messenger & evidence & & \\
\hline $\begin{array}{l}\text { Category } 2 \\
\text { Hub o Spoke }\end{array}$ & $\begin{array}{l}\text { Mixed } \\
\text { evidence }\end{array}$ & $\begin{array}{l}\text { Evidence used to } \\
\text { clamify pumpose and } \\
\text { likely effect }\end{array}$ & $\begin{array}{l}\text { Per Se / Rule } \\
\text { nf Reason }\end{array}$ \\
\hline Category 3: & No evidence & Evidence used to & Maybe under \\
\hline Preductable: & & show motive and & FICAdSS \\
\hline Agent & & $\begin{array}{l}\text { awareness in facily- } \\
\text { tating tacit collusion }\end{array}$ & or Article 102 \\
\hline $\begin{array}{l}\text { gory } 4: \\
\text { tal Eve }\end{array}$ & No evidence & No evidience & Unclear \\
\hline
\end{tabular}

\section{A. First Category: The Computer as Messenger}

In this simple scenario, humans use computers to directly execute their instructions. Such use may be subjected to a traditional enforcement approach. An agreement or concerted practice may be established as humans collude through the medium of computers. In this category, humans are the masters who map out the cartel. The computer algorithms serve as the messengers, in that the cartel members program the computers to help effectuate the cartel, and monitor and punish any deviation from the cartel agreement. ${ }^{46}$ To illustrate: in a classic cartel agreement, executives from rival firms secretly agree to fix prices, allocate markets or bids, or reduce output. ${ }^{47}$ Here, the executives, after colluding in secrecy, leave it to their computer algorithms to monitor and enforce the agreement.

Competition enforcers can rely on the case law involving an illicit agreement or concerted practice and use the concept of "object" 48 or

46. See id.

47. Scott D. Hammond, The Fly on the Wall Has Been Bugged--Catching an International Cartel in the Act, U.S. DEP'T OF JUSTICE (May 15, 2001), http://www.justice.gov/atr/public/spceches/8280.htm (ADM case).

48. Treaty on the Functioning of the European Union, pt. 3, tit. 7, ch. 1, § 1, art. 1, Mar. 25, 1957, 2012 O.J. (C 326) 88. The European courts and Commission have generally treated price-fixing, market-sharing and bid-rigging arrangements as having the object of restricting competition. Case T138/07, Schindler Holding Ltd. v. European Comm'n, 2011 E.C.R. 620. 
"per-se" illegality ${ }^{49}$ The implementation and monitoring of the agreement by the computer may reflect the scope of the agreement and its harm, but the computers' failure to effectuate the agreement does not affect the agreement's illegality. ${ }^{50}$ The stronger the evidence of an anticompetitive agreement in Category I, the lesser the need for intent evidence to establish the concurrence of wills. ${ }^{51}$

Still, the intent of the cartel members may play a significant role in establishing the violation and, as such, merits more detailed consideration. The law has long considered a person's intent for specific actions. ${ }^{52}$ The requisite evidence of intent for criminally prosecuted per se illegal offences, such as price fixing, is relatively modest. Lower U.S. courts have held that when the challenged activity is per se illegal under the antitrust laws, the government in criminal cases need only prove the existence of an agreement and that the defendant knowingly entered into the alleged agreement or conspiracy. ${ }^{53}$ Defendants' altruistic motives are legally irrelevant when the conduct is per se illegal..$^{54}$

49. Agreements among competitors that "tamper" with price structure are per se illegal. United States v. Socony-Vacuum Oil Co., 310 U.S. 150, 221 (1940) ("Even though the members of the pricefixing group were in no position to control the market, to the extent that they raised, lowered, or stabilized prices they would be directly interfering with the free play of market forces.").

50. Power Conversion, Inc. v. Saft Am., Inc., 672 F. Supp. 224, 227 (D. Md. 1987) ("Price-fixing is per se illegal regardless of whether the objective is to raise or lower market prices, whether the agreement is successful or not, and whether the prices were reasonable or not."). Thus, the Sherman Act reaches combinations formed for the purpose, and with the effect, of raising, depressing, fixing, pegging, or stabilizing prices. Antitrust plaintiffs need not prove that defendants fixed prices directly or controlled a substantial part of the commodity, no competition remained, or prices as a result wcrc uniform, inflexible, or unreasonable. Socony-Vacuum, 310 U.S. at 222, 224 n.59.

51. Ronald Cass \& Keith Hylton, Antitrust Intent, HARV. CTR. FOR BuS. \& Gov. 13-14 (2001), https:/sites.hks.harvard.edu/m-rebg/research/rpp/RPP-2001-12.pdf.

52. Morissette v. United States, 342 U.S. 246, 250-51 (1952); see also United States v. U.S. Gypsum Co., 438 U.S. 422, 436 (1978) ("We start with the familiar proposition that '[t]he existence of a mens rea is the rule of, rather than the exception to, the principles of Anglo-American criminal jurisprudence." ") (quoting Dennis v. United States, 341 U.S. 494, 500 (1951)); LYNN STOUT, CuLTIVATING CONSCIFNCF: HOW GOOD I AwS MAKF GOOD LAwS 206 (2011) ("Intent is so central to criminal liability that a person with bad intent can be sent to jail even if she harms no one."). The U.S. Supreme Court has also recognised the relevance of the antitrust defendant's intent, which can be inferred from the defendant's anticompetitive conduct or lack of a valid nonpretextual justification. Board of Trade of Chicago v. United States, 246 U.S. 231, 238 (1918) ("This is not because a good intention will save an otherwise objectionable regulation or the reverse; but because knowledge of intent may help the court to interpret facts and to predict consequences.").

53. See, e.g., United States v. Gillen, 599 F.2d 541, 545 (3d Cir. 1979) (holding that "in pricefixing conspiracies, where the conduct is illegal per se, no inquiry has to be made on the issue of intent beyond proof that one joined or formed the conspiracy"). The government need not prove the "perpetrator's knowledge of the anticipated consequences" or intent to produce the anticompetitive effects. Gypsum, 438 U.S. at 446 . Instead, "a finding of intent to conspire to commit the offence is sufficient; a requirement that intent go further and envision actual anti-competitive results would reopen the very questions of reasonableness which the per se rule is designed to avoid." United States v. Brown, 936 F.2d 1042, 1046 (9th Cir. 1991) (quoting United States v. Koppers Co., 652 F.2d 290, 296 n.6 (2d Cir. 1981)) (agreeing "with the express holdings of six other circuits, and the intimations of another, that Gypsum does not requirc proof of a defendant's intent to produce anticompetitive effects where the defendant is charged with a per se violation of the Sherman Act").

54. United States v. U.S. Gypsum Co., 340 U.S. 76, 87 (1950) ("Good intentions, proceeding under plans designed solely for the purpose of exploiting patents, are no defense against a charge of violation by admitted concerted action to fix prices for a producer's products, whether or not those products are validly patented devices."); Giboney v. Empire Storage \& Ice Co., 336 U.S. 490, 496 (1949) 
One example of the first category is the Topkins case, ${ }^{35}$ where the defendant and his coconspirators agreed to fix, increase, maintain, and stabilize prices of certain posters sold online on Amazon Marketplace. ${ }^{56}$ To implement their illegal agreement, the conspirators agreed to adopt specific pricing algorithms for the sale of the postcrs with the goal of coordinating changes to their respective prices. ${ }^{57}$

Another example of the use of computers to facilitate collusion is the Airline Tariff Publishing casc. ${ }^{58}$ The United States alleged that the defendant airlines used their computerized fare dissemination services to freely negotiate among themselves supra-competitive fares in multiple markets. ${ }^{59}$ No one questioned that the defendants' computerized fare dissemination system had a pro-competitive purpose in supplying travel agents with basic information about the airline fares for specific routes. ${ }^{60}$ The antitrust risks arose, however, when the defendant airlines also used this system as a forum to exchange information that was of limited or no use to consumers but was important to the other airlines in communicating and agreeing upon supra-competitive fares. ${ }^{61}$

The Antitrust Division asserted that the defendant airlines essentially signaled their concurrence or disagreement to entreaties to raise fares and/or eliminate discounted fares through the First and Last Ticket Dates. ${ }^{62}$ Essentially, the defendant airlines communicated among themselves relatively costless proposals to change fares through these footnote designators with First and Last Ticket Dates. ${ }^{63}$ They employed sophisticated computer programs to process all this fare information, which enabled them to monitor and analyze their competitors' responses to current and future fares on certain roules. ${ }^{64}$ These negotiations at times would link fare changes among different routes, and continue for several weeks until all the airlines had indicated their commitment to the fare in-

("More than thirty years ago this Court said ... 'It is too late in the day to assert against statutes which forbid combinations of competing companies that a particular combination was induced by goad intentions." (quoting International Harvester Co. v. Missouri, 234 U.S. 199, 209 (1914))); SoconyVacuum, 310 U.S. at 221-22 (noting that the Sherman Act "has no more allowed genuine or fancied competitive abuses as a legal justification for such schemes than it has the good intentions of the members of the combination."); Nash v. United States, 229 U.S. 373, 377 (1913) ("The very meaning of the fiction of implied malice in such cases at common law was, that a man might have to answer with his life for consequences which he neither intended nor foresaw.").

55. Press Release, Dep't of Justice, Former E-Commerce Executive Charged with Price Fixing in the Antitrust Division's First Online Marketplace Prosecution (Apr. 6, 2015), http://www.justice. gov/opa/pr/former-e-commerse-executive-charged-price-fixing-antitrust-divisions-first-online-market place.

56. Id.

57. Id.

58. United States v. Airline Tariff Publ'g Co., 836 F. Supp. 9 (D.D.C. 1993).

59. Id. at 12 .

60. Id. at 14 .

61. See Complaint at 甲 $927-33$, United States v. Airline Tariff Publ'g Co., 836 F. Supp. 9 (D.D.C. 1993) (No. 92-2854).

62. Airline Tariff Publ'g Co., 836 F. Supp. at 12.

63. See Complaint at $\llbracket \mathbb{\Psi} 27-33$, United States v. Airline Tariff Publ'g Co., 836 F. Supp. 9 (D.D.C. 1993) (No. 92-2854).

64. See id. 
creases by filing the same fares in the same markets with the same First Ticket Date. ${ }^{65}$ Likewise, the airlines used the Last Ticket Dates in connection with the footnote designators to communicate proposals to eliminate discounted fares currently being offered to consumers. ${ }^{66}$ Not only did this computerized fare dissemination system enable the defendants to negotiate supra-competitive fares, it importantly enabled them to verify that such fares would stick and signal retaliatory measures against any airline that did not go along with specific fares for specific routes ${ }^{67}$

In a modified scenario of the above case, the airline executives would broadly agree not to compete along certain routes and program their computers to ensure that each airline is allocated its set of customers, to monitor any deviations, and to react automatically to any defections. Importantly, the computers here are used to execute the task which they were set, using pre-loaded data and orders. While faster than their creators, the computer algorithms reflect, and are limited by, the amalgamation of human instructions. The computers simply help cxccutc the humans' anticompetitive agreement.

\section{B. Second Category: Hub and Spoke}

Here, competitors use the same (or a single) algorithm to determine the market price or react to market changes. In this scenario, the common algorithm, which traders use as a vertical input, leads to horizontal alignment.

$*$

65. See id. ๆ $27-33$

66. See id.

67. This information exchange greatly facilitated tacit collusion, and as noted by the Division, it was of little benefit to consumers. Airline Tariff Publ'g Co., 836 F. Supp. at 14. Some defendants disputed this claim, submitting numerous affidavits from travel agents praising the airlines' policy of advanced notice, and arguing that such signalling was employed in geographic markets where only one airline had market power. Id. The travel agents did not, however, have access to some of this information (such as the footnote designators), and thus could not readily determine all of the airlines' contemplated changes to fares. Nor could the agents (unlike the airlines) readily determine the relationships between proposed fare increases for certain routes and the elimination of discounted fares on other routes. See id. at 11. Moreover, the pricing information, asserted the Division, was unreliable and misleading, in particular because the airlines changed the ticket dates often. See id. at 10. The Division's consent decrees attempted to shift the lever toward promoting information of use to the consumcrs. The decrees did not prohibit the posting of airfare pricing; rather, the defendants were prohibited from posting fare information of little significance to the consumer, namely Last Ticket Dates, with the exception of those used in advertised promotions, and First Ticket Dates. Id. at 12 . Thus, the airline's posted fares would have some significance for the consumer, as the travel agents could immediately purchase the ticket that day for that fare. Likewise, by restricting the airlines from using Last Ticket Dates except under advertised commitments, the decrees ended the "costless communication" among the defendants about which discounts should be removed. ARIEL EZRACHI \& MAURICE E. STUCKE, VIRTUAL COMPETITION: THE PROMISE AND PERILS OF THE ALGORITHM-DRIVEN ECONOMY 270 (2016). The decrees did not eliminate the possibility of tacit coordination. Rather, they made such negotiations costlier for the airlines by imposing some risk on the price leader. Id. Moreover, when one airline recently violated this decree by signaling a price increase through a prohibited mechanism, it resulted in a $\$ 3$ million civil penalty. Id. 
To illustrate the possible anticompetitive effect, consider the price algorithm Uber uses to determine the contract pricing for its services. ${ }^{68}$ That algorithm has been referred to as "algorithmic monopoly" because it may mimic a perceived competitive price rather than the true market price. ${ }^{69}$ As more drivers usc Ubcr's algorithm, one may wonder what its effect on the market price may be. Reported instances in which the algorithm has pushed the price up raise challenging questions as to the algorithm's possible manipulation of the perceived market price. ${ }^{70}$ With a growing number of users and providers, the alternative universe created by the algorithm may provide an opportunity for exploitation and coordinated price increases. ${ }^{71}$

Another case is where firms electronically send their cost data to a third party that suggests (or sets) the profit-maximizing price. If many competitors use the same third-party pricing strategist, a hub-and-spoke conspiracy could ensue.

In this second category, a vertical agreement between the algorithm developer and user is not contested. The competitors-while agreeing to use the algorithm-did not necessarily agree to fix the prices for taxi services. It is the parallel use of the same algorithm which may give rise to concerns.

From an enforcement perspective, this category is particularly challenging because it may require one to delve into the heart of the algorithm and establish whether it is designed in a way that would or may lead to exploitation. If the algorithm is designed to facilitate collusion among its users, then we would have a classic hub-and-spoke conspira$c y,{ }^{72}$ a similar review as the one discussed in our first category would apply. $^{73}$

68. Kevin Kononenko, How Does Uber's Dispatch Algorithm Work?, QUORA (Apr. 17, 2016) https://www.quora.com/How-does-Ubers-dispatch-algorithm-work; Eric Posner, Why Uber Will-and Should-Be Regulated, SLATE (Jan. 5, 2015, 2:49 PM), http://www.slate.com/articles/news_and _politics/view_from_chicago/2015/01/uber_surge_pricing_federal_regulation_over_laxis_and_car_ride _services.html; James Surowiecki, In Praise of Efficient Price Gouging, MII TECH. KEv. (Aug. 19, 2014), https://www.technologyreview.com/s/529961/in-praise-of-efficient-price-gouging/.

69. Kononenko, supra note 68 .

70. Posner, supra note 68 .

71. Id.

72. As the Supreme Court noted, "an unlawful conspiracy may be and often is formed without simultaneous action or agreement on the part of the conspirators." Interstate Circuit v. United States, 306 U.S. 208, 227 (1939). In that case, the movie theater owner approached each movie distributor individually, told each movie distributor of the contemplated conspiracy, told each movie distributor that the other movie distributors would be invited to join the conspiracy, and said that cooperation of all eight distributors was essential for the conspiracy to work. By giving their adherence to the conspiracy and agreeing to participate in it, both the movie theater owner (the hub) and eights distributors (spokes) would be liable.

73. See, e.g., Tesco v. Office of Fair Trading (Case 1188/1/1/11) Competition Appeal Tribunal, [2012] CAT 31 (U.K.). Indirect information exchange through a third party will be condemned where two phases are present: (1) Retailer A discloses to supplier B its future pricing, with the intention that $B$ will pass that information to other retailers to influence market conditions; (2) $C$. receives the information from $B$, knowing the circumstances in which it was disclosed by $\Lambda$ to $B$; and makes use of that information in determining its own future pricing intentions. 
Absent such anticompetitive design, the competition authority could explore the possible adverse effect of these vertical agreements to use the algorithm under the more forgiving Rule-of-Reason standard. Here, intent evidence may be used to assess the nature of the agreement (i.e., is it purely vertical or is it effectively a horizontal agreement among competitors), its likely competitive consequences, whether to categorize the conduct as a hard-core offense, and whether to prosecute civilly or criminally. ${ }^{74}$

In evaluating collaborations among competitors, the agencies consider intent evidence, which "may aid in evaluating market power, the likelihood of anticompetitive harm, and claimed procompetitive justifications where an agreement's effects are otherwise ambiguous." 75 Thus, in determining antitrust liability, courts will consider the firms' intent in using the algorithms, i.e., whether they (1) intended a clearly illegal result, such as agreeing to fix prices, or (2) acted with knowledge that illegal results, which actually occurred, were "probable." 76

\section{Third Category: Predictable Agent}

In this category, each firm unilaterally uses the computer as part of a subtle strategy to enhance market transparency and predict behavior. Under certain market conditions, the industry-wide use of algorithms transforms the market dynamic to effectively enable conscious parallelism and higher prices. In these new market conditions, the pricing algorithms can coordinate in one of two ways.

The first involves the algorithms reaching a similar common understanding that is not explicitly negotiated but comes about with the computer learning to quickly detect and punish rivals' price cutting. As a result, the algorithms are less likely to deviate from the supra-competitive price. $^{77}$

74. U.S. DEP'T OF JUSTICE, ANTITRUST Division MANUAL III-12 (2015), https://www.justice. gov/atr/file/761166/download (noting how the Department of Justice would not prosecute the offence criminally if "there is clear evidence that the subjects of the investigation were not aware of, or did not appreciate, the consequences of their action").

75. Federal Trade Comm'n \& U.S. Dep't of Justice, Antitrust Guidelines for Collaborations Among Competitors 12 n.35 (Apr. 2000), https:/www.ftc.gov/sites/default/files/documents/public _events/joint-venture-hearings-antitrust-guidelines-collaboration-among-competitors/ftcdojguidelines2.pdf. Likewise, the European Commission assesses "whether or not an agreement has as its object the restriction of competition," based on "a number of factors," including evidence of the parties' subjective intent. Guidelines on the Application of Article 81(3) of the Treaty, at 922,2004 O.J. (C 101) 97, 100. See also U.S. Dep't of Justice \& Federal Trade Comm'n, Horizontal Merger Guidelines § 2.2.1 (Aug. 19, 2010) [hereinafter 2010 Merger Guidelines] ("Explicit or implicit evidence that the merging parties intend to raise prices, reduce output or capacity, reduce product quality or variety, withdraw products or delay their introduction, or curtail research and development efforts after the merger, or explicit or implicit evidence that the ability to engage in such conduct motivated the merger, can be highly informative in evaluating the likely effects of a merger.").

76. United States v. U.S. Gypsum Co., 438 U.S. 422, 444-46 (1978) (concluding that "action undertaken with knowledge of its probable consequences and having the requisite anticompetitive effects can be a sufficient predicate for a finding of criminal liability under the antitrust laws").

77. 2010 Merger Guidelines, supra note $75, \S 7$. 
Alternatively, the computers can engage in parallel accommodating conduct, whereby "each rival's response to competitive moves made by others is individually rational, and not motivated by retaliation or deterrence nor intended to sustain an agreed-upon market outcome, but nevertheless emboldens price increases and weakens competitive incentives to reduce prices or offer customers better terms." ${ }^{\prime 78}$

Unlike our first two categories, the firms in Category III have not jointly agreed to anything. The firms -in unilaterally creating and implementing the algorithms - did not intend a clearly illegal result, such as agreeing to fix prices. Each firm had an independent economic selfinterest to develop and rely on the algorithms; indeed, it may be contrary to the firm's self-interest to rely on human pricing or trading. Nor have the computers "agreed" as conventionally understood to fix prices.

To illustrate this possibility, imagine an oligopolistic market in which transparency is limited and therefore conscious parallelism cannot be sustained. Under these relatively competitive market conditions, the firms will compete as expected. Now, think of the basic conditions for tacit collusion/conscious parallelism. Suppose that to shift pricing decisions from humans to computers, each firm must increase price transparency. Now both the firm's customers and rivals can promptly observe all the competitively significant terms. Indeed, competitors may, like highspeed traders, have the incentive to invest in technology that allows them to see the competitively significant terms a few minutes or seconds before customers. Also, suppose that the products are relatively homogeneous. By shifting pricing decisions to computer algorithms, competitors increase transparency, reduce strategic uncertainty (as the pricing algorithm cannot grant secretive discounts), and thereby stabilize the market. ${ }^{79}$ In such a market, tacit collusion may be sustained, leading to supracompetitive prices.

Here, tacit collusion could not have been easily sustained without computers. In some ways, it is akin to the use of computers at the blackjack table. The computers could count all the cards in the multiple decks to predict the likelihood of receiving a desired card. To compete, you would likely want a computer as well. So too each firm-in unilaterally shifting to pricing algorithms - would bring the market reality closer to that necessary for conscious parallelism, leading to higher prices. Importantly, the price increase is not the result of express collusion (Category I), but rather the natural outcome of tacit collusion. While the latter is not itself illegal - as it concerns rational reaction to market characteristics - one may ask whether its creation through "artificial" means should give rise to antitrust intervention.

This scenario raises several enforcement challenges. In essence, conscious parallelism takes place at two levels. First, when configuring

78. Id.

79. See Mehra, supra note 27 (showing how pricing algorithms can promote tacit collusion under a Cournot model). 
the machines, each human, independently and without collusion, knows that when possible, a dominant strategy may be to follow the price increase of others. Furthermore, each person knows that if other firms settle for a similar program, an equilibrium may be established above competitive levels.

This conscious parallclism at the human level leads to the programing of machines which are aware of possible conscious parallelism at the market level. The computer is therefore set up to monitor the market and explore the likelihood of establishing interdependence of action, without venturing into illegal concerted practice or illicit agreement. The computer may also be programmed to punish deviations from a possible tacit agreement and to identify maverick firms which depart from the equilibrium.

In what follows, we further elaborate on the market dynamics and enforcement challenges that Category III presents.

\section{Market Dynamics}

Our scenario concerns similarly designed algorithms, which were developed independently, and are used to monitor activity on the market and rationally follow price leadership. That activity may stabilize interdependence on a market, subsequently leading to higher prices. Several key features are noteworthy in our algorithm-led marketplace.

First, markets are typically more vulnerable to coordinated conduct when a firm's "significant competitive initiatives can be promptly and confidently observed by that firm's rivals." 80 This is more likely when "the terms offered to customers are relatively transparent." nario, for the computer programs to optimize pricing, key market data must be digitalized and accessible. Each firm programs its computer to maximize profit by reacting to other market movements. One may, for instance, imagine the use of historic data to calibrate the computer's dominant strategy. As such, when operating in a digitalized market environment with a few players, the pricing algorithms may foster greater transparency and anticipate each other's moves. In such a scenario, computers can rapidly calculate the profit implications of myriad moves and counter-moves, police deviations and apply strategies to punish deviations, and subsequently sustain parallel behavior.

Furthermore, computer algorithms are quicker to observe price and demand changes, and respond (including tit-for-tat) in adjusting prices for relatively homogeneous products. Moreover, computers, to the extent they are plugged into their customers' warehouses and amassing other data (such as shipment records), can identify if competitors are increasing sales (including expanding into serving new categories of customers, such as institutional buyers, or new territories). Thus, computers,

80. 2010 Merger Guidelines, supra note $75, \S 7.2$.

81. Id. 
in quickly proccssing their market and customers' proprietary data, may be more effective in monitoring rivals' prices or customers, which not only increases transparency but the risk of coordination.

Sccond, markets are typically more vulnerable to coordinated conduct "if a firm's prospective competitive reward from attracting customers away from its rivals will be significantly diminished by likely responses of those rivals," which "is more likely to be the case, the stronger and faster are the responses the firm anticipates from its rivals." ${ }^{82}$ Here, computer algorithms can process the pricing-rclated data quickly to determine price. In markets where customers can easily switch between suppliers and where the goods are homogenous, computer algorithms can quickly detect price reductions by a rival and effectively deprive the rival of any significant sales. The greater the price transparency, the quicker the competitive response, the less likely the first-mover will benefit, and the less likely a price reduction. Industry-wide use of "meetingcompetition" clauses ${ }^{83}$ is likely to further increase the likelihood of assimilation through machine learning.

Markets are thus typically more vulnerable to coordinated conduct when each firm would be unlikely to profit from its competitive initiatives. For example, suppose Firm A's computer lowers the price. If Firm A's rivals immediately access the data and lower their prices, then Firm A would unlikely increase sales. Given the velocity with which the pricing algorithms can adjust, Firm $\mathrm{A}$ would unlikely develop amongst its customers the reputation of a price discounter. Accordingly, Firm A will have less incentive to discount.

Third, given the velocity of pricing decisions, firms would no longer have to rely on lengthy (e.g., thirty-day) advance price announcements, where scllcrs publish price changes ahead of their effective dates and await the competitive response to the announced price increase. Computers can have multiple rounds whereby one firm increases price and the rival computers respond immediately without the risk that the firm that initiates the price increase will lose many customers to rivals. Essentially, companies now may need only scconds, rather than days, to signal price increases to foster collusion.

Fourth, the pricing algorithms can engage in limit pricing to discourage would-be entrants.

Fifth, the stability needed for tacit collusion is further enhanced by the fact that computer algorithms are not likely to exhibit human biases. Human biascs can always be reflected in the programming code, but if some biases are minimized (such as loss aversion, sunk cost fallacy, and framing effects), then the algorithm acts consistently on System 2 thinking, rather than System 1.84 The computer does not fear detection and

82. Id.

83. Id. 2011).

84. See generally Daniel KaHNEMAn, ThInkING, FAST AND Slow (Farrar, Straus \& Giroux 
possible financial penalties or incarceration; nor does it respond in anger. Moreover, the universe may be closed with each algorithm sharing a common interest (profits) and inputs (same data) that may lead to stable, durable tacit collusion among a larger number of players as long as they can detect and appreciate the type of algorithm others are using. As computers assimilate, this becomes easier to predict.

\section{Enforcement Challenges}

The main enforcement challenge in this category concerns the legality of conscious parallelism. A rational reaction by competitors to market dynamics, in itself, is not illegal. ${ }^{85}$ When such legal behavior, absent communication or collusion, leads to an equilibrium being established above competitive levels - it does not trigger antitrust intervention. After all, one cannot condemn a firm for behaving rationally and independently on the market. ${ }^{86}$

The fact that tacit collusion is legal, however, does not mean it is desirable. Indeed, in merger analysis, competition agencies may condemn a transaction that makes tacit collusion likelier. ${ }^{87}$ This is because the transaction, in effect, changes the normal competitive conditions. In our case, the use of advanced algorithms similarly transforms an oligopolistic market in which transparency is limited-and therefore conscious parallelism cannot be sustained - to a market susceptible to tacit collusion/conscious parallelism in which prices will rise.

The challenge for enforcers stems from the fact that price increases are not the result of express collusion but rather the natural outcome of tacit collusion. While tacit collusion is legal, should its creation through an enhanced computerized environment give rise to antitrust intervention? The question, therefore, is whether one may condemn the creation of a transparent market in which monitoring and punishment mechanisms are present. Should the man-made formation of the conditions for tacit collusion through the use of advanced algorithms be condemned as illegal? And if so, under what conditions? Can the competition agency impute the presence of an illicit agreement or understanding among the competitors to use similar algorithms to dampen competition? ${ }^{88}$

85. EZRACHI \& STUCKE, supra note 67, at 79.

86. See, e.g., Case C-199/92 P, Hüls v. Comm'n, 1999 E.C.R. I-4287; Joined Cases C-89, 104, 114 116, 117, 125, 129/85, Ahlström v. Comm'n, 1993 E.C.R. I-1307; Case T-442/08, CISAC v. Comm'n, 5 C.M.L.R. 15 (2013).

87. See 2010 Merger Guidelines, supra note $75, \S 7.2$.

88. The plaintiff can allege that the defendant firms collectively agreed to use these algorithms, namely their collective agreement to use a facilitating device that fosters tacit collusion. See Todd v. Exxon Corp., 275 F.3d 191 (2d Cir. 2001). The benefit of this approach is that it may be easier to prove the industry agreed to use algorithms (especially to ensure their interoperability) and knew that its rival firms' algorithms had similar reward structures than it is to prove an agreement to fix prices. The downsides of this approach are the cost, duration, and unpredictability of a rule-of-reason case, and the difficulty for the court in weighing the pro-competitive benefits of product developments with the anticompetitive effects. 
Most jurisdictions' competition provisions require proof of agreement among the competitors to change the market dynamics. ${ }^{89}$ Such proof may, however, be hard to obtain. This may be so particularly as the strategy to develop the algorithm, to begin with, was a result of conscious parallelism. Evidence of exchange and sharing of information, or personnel movement from one company to another, may facilitate the finding of illicit concerted practice. One should acknowledge, however, that evolution dictates that the stronger, more powerful algorithms will likely prevail and dominate. This reality naturally fosters assimilation of systems between various computer developers and companies. A decision not to opt for the most advanced algorithm may be irrational. It would be as if a stock firm would want to rely on human floor traders when most trading is automated. The use of similar algorithms may further help stabilize the market. Computers can more easily detect the market behaviors of competitors, anticipate the rival algorithms' likely reactions to different competitive responses, and opt the path that given the competitive reactions will maximize profits, which may often be the path toward conscious parallelism..$^{90}$

Absent evidence of an agreement to change market dynamics, most competition agencies may lack enforcement tools, outside merger control, that could effectively deal with the change of market dynamics to facilitate tacit collusion through algorithms. In some instances, one may consider other provisions that do not require proof of an agreement.

In the United States, for instance, the Federal Trade Commission ("FTC") can bring this claim under $\S 5$ of the FTC Act, which does not require an agrcement but only a showing of an "unfair practice." Many states have similar statutes. ${ }^{92}$ But the FTC has been unsuccessful in bringing these types of claims as evident in Boise Cascade ${ }^{93}$ and Ethyl..$^{94}$ If the court adopts the standard in Ethyl, the FTC would need to show either: (1) evidence that defendants tacitly or expressly agreed to a facilitating device to avoid competition, or (2) oppressiveness, such as (a) evidence of defendants' anticompetitive intent or purpose or (b) the absence of an independent, legitimate business reason for defendants' conduct. ${ }^{95}$ Accordingly, in Category III, the defendants may be liable if, when developing the algorithms or in seeing the effects, they were: (1) motivated to achieve an anticompetitive outcome, or (2) aware of their actions' natural and probable anticompetitive consequences.

89. George A. Hay, Horizontal Agreements: Concept and Proof, 51 ANTTTRUST BulLETIN 877, $877-78(2006)$.

90. Stuckc \& Ezrachi, supra note 45.

91. 15 U.S.C. $\$ 45(\mathrm{a})$ (2012).

92. See, e.g., 815 Ill. COMP. STAT. 510/2 (2001)

93. Boise Cascade Corp. v. Fed. Trade Comm'n, 837 F.2d 1127, 1148 (D.D.C. 1988).

94. Ethyl Corp. v. Fed. Trade Comm'n, 729 F.2d 128, 142 (2d Cir. 1984).

95. Id. at $139-40$. 


\section{Fourth Category: Digital Eye-Optimizing Performance}

The third category removed the legal concept of agreement and therefore restricted the range of enforcement tools. The application of $\S 5$ of the FTC Act, for example, was contingent on anticompetitive motive or intent. ${ }^{96}$ In our last category, we completely remove the legal concept of intent. In doing so, we exclude $\S 5$ from the available enforcement tool-box. We consider the possibility that the computer developers foresee tacit collusion as one of many possible outcomes-but not necessarily the likeliest outcome. Smart machines may independently optimize profitability by reaching conscious parallelism - or they may not. Note that in this category, the algorithm developers are not necessarily motivated to achieve tacit collusion; nor could they predict when, how long, and how likely it is that the industry-wide use of algorithms would yield tacit collusion. Nor is there any intent or attempt by the developers and user of the algorithm to facilitate conscious parallelism. The firm "merely" relies on AI.

In this last category, we assume that the computer is set a target such as the maximization of profit, optimization of performance, etc. The algorithm-using advanced neural networks - then operates autonomously to achieve the target. The actions of the algorithm are governed by limiting principles which prohibit illegal activity such as price fixing or market sharing. ${ }^{97}$ Subject to these restrictions, they do, however, allow self-learning and experimentation.

In this category, we consider the possibility that a self-learning machine may find the optimal strategy is to enhance market transparency and thereby sustain conscious parallelism or foster price increases. Importantly, tacit coordination - when executed-is not the fruit of explicit human design but rather the outcome of evolution, self-learning, and independent machine execution. ${ }^{98}$

As noted earlier, conscious parallelism is legal. The question is whether such practices, when implemented by smart machines in a predictable digitalized environment, ought to be condemned. With machines rapidly adjusting to new data and competitive scenarios, the users and designers may know that increased transparency and supra-competitive prices may occur, but cannot predict ex ante when, for how long, and to what extent.

One should acknowledge the different levels of sophistication which characterize different machine-learning algorithms, agents, and market players. Faster, smarter operators may benefit from market transparency which is unavailable to others. Furthermore, their ability to react swiftly to change may leave others outside the market, thus increasing barriers

96. Id. at 139 . senger.'

97. Absent such limiting principles, the scenario would be similar to the First Category of 'mes-

98. See generally Jack Robles, Evolution and Long Run Equilibria in Coordination Games with Summary Statistic Payoff Technologies, 75 J. ECON. THEORY 180, 180-93 (1997). 
to entry. Slower agents may be pushed outside the inner transparency circle and only gain access to it when leading agents opt not to react. ${ }^{99}$

As with the third category, the presence of similar-minded agents may facilitate collusion. A self-learning machine may find it easier to tacitly collude with similar machines. It may be easier for such computers to adjust to the changing market reality, and anticipate and understand moves made by other machines, which are designed along similar lines. Programs and computers are easily duplicated - a reality in which a market is operated by similar-minded agents should be anticipated.

Interestingly, in a market reality in which such future collusion is possible, the programmers' designers may favor the use of similar algorithms. This seemingly benign decision may have significant implications once learning has taken place. The similar machines are more likely to "understand" one another and stabilize a collusive outcome. ${ }^{100}$ Importantly, recall that on the "factory floor" these computers have no specific commands which may trigger collusion. It is the self-learning in a transparent market occupied by similar-minded agents with the same profit maximizing goal which leads to collusion.

Despite similar effects as in Category III, the lack of evidence of an anticompetitive agreement or intent in Category IV may result in AI self-learning escaping legal scrutiny.

\section{REFLECTIONS AND POLICY CONSIDERATIONS}

Coordinated, accommodating, or interdependent responses among computers raise challenging technical, enforcement, and ethical questions. These questions differ depending on the category of technological implementation.

In the Messenger category, the computer serves as the long arm of cartel members. Here, it merely provides an implementation platform and thus raises few challenges as to the presence of agreement (or intent).

The Hub and Spoke category concerns the parallel use of the same algorithm (pursuant to vertical agreements) that facilitate horizontal collusion. The first challenge concerns the technological decoding of the algorithm and related documentary evidence to determine whether it is designed to skew the market prices. In the affirmative, the scenario resembles the Messenger category and is per se illegal. If not, the effects of such a network on price, usage, and quality should be considered.

The Predictable Agent category raises challenging questions as to the ability to condemn the creation or strengthening of conscious parallelism through a sophisticated algorithm. Could superior technology,

99. Ultimately, as recognised by competition authorities, "[t]he ability of rival firms to engage in coordinated conduct depends on the strength and predictability of rivals' responses to a price change or other competitive initiative." 2010 Merger Guidelines, supra note $75, \S 7$.

100. Id. 
which enhances transparency, be targeted and condemned without the risk of chilling innovation and investment?

The Digital Eye category raises similar difficulties with respect to conscious parallelism, but increases the complexity of identifying intent and distinguishing between the operation of the machine and that of its designer.

In what follows, we review some of the legal and analytical challenges raised by the Predictable Agent and Digital Eye categories.

\section{A. Determining the Primary Purpose for Increasing Transparency}

Market transparency serves as a central variable that facilitates conscious parallelism in Categories III (Predictable Agent) and IV (Digital Eye). ${ }^{101}$ Yet, market transparency is a central pillar of effective competitive markets. ${ }^{102}$ Greater transparency enables information to flow freely, which may increase the competitive pressure ${ }^{103}$ After all, the model of perfect competition assumcs that buyers will have full information on prices and product characteristics, and the model equilibrium predicts uniform and competitive prices for comparable goods. ${ }^{104}$ In a digitalized environment such as the Internet, greater price transparency may reduce the buyers' search costs in finding the best deal, whether for airline tickets or chainsaws. ${ }^{105}$ It may reduce the sellers' ability to price discriminate. ${ }^{106}$

Thus, if the algorithms increase market transparency, one challenge confronting the courts and competition authorities is that the defendants will often have an independent, legitimate business reason for their conduct. Courts and the enforcement agencies may be reluctant to restrict this free flow of information in the marketplace. Its dissemination, observed the Supreme Court, "is normally an aid to commerce"10 and "can in certain circumstances increase economic efficiency and render markets more, rather than less, competitive." 108 Indeed, concerted action to reduce price transparency may itself be an antitrust violation. ${ }^{109}$

101. See supra Sections III.C-D.

102. See World Economic Forum, The 12 Pillars of Competitiveness, http://reports.weforum. org/global-competitiveness-report-2014-2015/methodology/ (last visited Aug. 9, 2017).

103. ORganisation FOR ECONOMIC CO-OPERATION AND DEVElopMENT (OECD), UNILATERAL DISCLOSURE OF INFORMATION WITH ANTICOMPETITIVE EFFECTS 24 (2012), www.oecd. org/daf/competition/Unilateraldisclosureofinformation2012.pdf.

104. Id. at 11 ("Market transparency is a necessary attribute for the model of perfect competition as it increases efficiency by reducing customers' search costs and allowing suppliers to benchmark their performance with that of their competitors.").

105. $I d$.

106. Id.

107. Sugar Inst., Inc. v. United States, 297 U.S. 553, 598 (1936).

108. United States v. U.S. Gypsum Co., 438 U.S. 422, 441 n.16 (1978); see also RICHARD A. POSNER, ANTITRUST LAw 160 (2d ed. 2001) (generally, the more information sellers have about their competitors' prices and outpul, the more efficiently the market will operate)

109. See, e.g., Press Release, Fed. Trade Comm'n, Funeral Directors Board Settles with FTC (Aug. 16, 2004), http://www.ftc.gov/news-events/press-releases/2004/08/funeral-directors-board-settlesftc. (discussing the board's prohibition on licensed funeral directors advertising discounts deprived 
Thus, one may find it difficult to fine-tune the enforcement policy to condemn "excessive" market transparency. This may be particularly challenging when the information and data are otherwise available to consumers and traders and it is the intelligent use of that information which facilitates conscious parallelism.

So, if humans program the computer to optimize profit and know that by reacting to changing market conditions through self-lcarning the computer will likely find collusion as the dominant strategy, are they liable? Perhaps - if there is strong evidence of anticompetitive intent. If the executives, for example, call their algorithm Gravy, and tinker with it to better manipulate the market, and boast about this in their internal emails - as was the Securities and Exchange Commission's ("SEC") case against Athena Capital Research - then liability is likely. ${ }^{110}$

In 2014, the SEC for the first time sanctioned a high-frequency trading firm, Athena Capital Research, for manipulating the market by "placing a large number of aggressive, rapid-fire trades in the final two seconds of almost every trading day during a six-month period to manipulate the closing prices of thousands of NASDAQ-listed stocks."111 The SEC found that Athena used complex computer programs to manipulate the stocks' closing prices. ${ }^{112}$ The sophisticated algorithm, code-named Gravy, engaged in a practice known as "marking the close" in which stocks were bought or sold near the close of trading to affect the closing price: "[ $t$ ]he massive volumes of Athena's last-second trades allowed Athena to overwhelm the market's available liquidity and artificially push the market price - and therefore the closing price-in Athena's favor." $" 113$

Athena's employees, the SEC alleged, were "acutely aware of the price impact of its algorithmic trading, calling it 'owning the game' in internal e-mails." 144 thena employees "knew and expected that Gravy im-

consumers of truthful information); Press Release, Fed. Trade Comm'n, Arizona Trade Association Agrees to Settle FTC Charges It Urged Merubers lu Restrain Cumpetitive Advertising (Feb. 25, 1994) (1994 WL 184107 (F.T.C.)) (highlighting a trade association's illegal agreement with members to restrict nondeceptive comparative and discount advertising and advertisements concerning the terms and availability of consumer credit); OECD, supra note 103, at 183, 185-86 (citing examples of U.S. enforcement agencies secking to incrcasc price transparency). But sce, InterVest, Inc. v. Bloomberg, L.P., 340 F.3d 144 (3d Cir. 2003) (lack of price transparency in bond market not illegal if consistent with unilateral conduct).

110. In re Athena Capital Res, LLC, 3950 S.E.C. No. 3-16199 (2014).

111. Press Release, Sec. Exch. Comm'n, SEC Charges New York-Based High Frequency Trading Firm with Fraudulent Trading to Manipulate Closing Priccs (Oct. 16, 2014), https:/www.sec. gov/news/press-release/2014-229\#.VEOZlfldV8E.

112. In re Athena Capital Res., supra note 110.

113. SEC Charges New York-Based High Frequency Trading Firm with Fraudulent Trading to Manipulate Closing Prices, supra note 111.

114. Id. As the SEC alleged, Athena's manipulative scheme focused on trading to imbalance securities at the close of the trading day:

Imbalances occur when there are more orders to buy shares than to sell shares (or vice versa) at the close for any given stock. Every day at the close of trading, NASDAQ runs a closing auction to fill all on-close orders at the best price, one that is not ton distant from the price of the stock just before the close. Athena placed orders to fill imbalances in securities at the close of trading, 
pacted the price of shares it traded, and at times Athena monitored the extent to which it did. For example, in August 2008, Athena employees compiled a spreadsheet containing information on the price movements caused by an early version of Gravy." 115 Athena configured its algorithm Gravy "so that it would have a price impact."116 In calling its marketmanipulation algorithm "Gravy," and exchanging a string of incriminating e-mails, the company did not help its case. Without admitting guilt, Athena paid a $\$ 1$ million penalty. ${ }^{117}$

This case is illustrative. Automated trading can increase market transparency and efficiency, but can also lead to market manipulation. ${ }^{118}$

Finding the predominant purpose for using an algorithm will not always be straightforward. Athena, for example, challenged the SEC's allegations that it engaged in fraudulent activity: "[w]hile Athena does not deny the Commission's charges, Athena believes that its trading activity helped satisfy market demand for liquidity during a period of unprecedented demand for such liquidity." 119 A court might agree. Companies also can learn from Athena and be more circumspect in their emails.

Moreover, reliance on intent evidence does not help enforcers in Category IV, where consumers are still harmed by the conscious parallelism facilitated by industry-wide use of pricing algorithms.

\section{B. Advanced Safeguards}

A potential solution to increased transparency and cooperation may be to require firms to disclose publicly the data used in their algorithms. When the data exchange is asymmetrical-namely, the data is not provided or valuable to the company's and its competitors' customers - the dissemination of such information among competitors, while not per se

and then traded or "accumulated" shares on the continuous market on the opposite side of its order.

According to the SEC's order, Athena's algorithmic strategies became increasingly focused on ensuring that the firm was the dominant firm - and sometimes the only one-trading desirable stock imbalances at the end of each trading day. The firm implemented additional algorithms known as "Collars" to ensure that Athena's orders received priority over other orders when trading imbalances. These eventually resulted in Athena's imbalance-on-close orders being at least partially filled more than $98 \%$ of the time. Athena's ability to predict that it would get filled on almost every imbalance order allowed the firm to unleash its manipulative Gravy algorithm to trade tens of thousands of stocks right before the close of trading. As a result, these stocks traded at artificial prices NASDAQ then used to set the closing prices for on-close orders as part of its closing auction. Athena's high frequency trading scheme enabled its orders to be executed at more favorable prices.

115. In re Athena Capital Res., supra note 110, II 34.

116. Id. श 36 .

117. SEC Charges New York-Based High Frequency Trading Firm with Fraudulent Trading to Manipulate Closing Prices, supra note 111.

118. Peter J. Henning, Why High-Frequency Trading Is So Hard to Regulate, N.Y. Trmes (Oct. 20, 2014, 1:40 PM), https://dealbook.nytimes.com/2014/10/20/why-high-frequency-trading-is-so-hard-toregulate/.

119. Steve Goldstein, High-Frequency Trading Firm Fined for Wave of Last-Minute Trades, MARKETWATCH (Oct. 16, 2014, 4:42 PM), http://www.marketwatch.com/story/high-frequency-tradingfirm-fined-for-wave-of-last-minute-trades-2014-10-16. 
illegal, carries a high antitrust risk; the risk is especially high when its exchange is unlikely to promote overall efficiency and is likely to (or in fact did) promote tacit collusion. ${ }^{120}$

The problem is that information asymmetry, while relevant in the days when competitors exchanged printed price lists and e-mails, is less relevant with machine learning where the computers process a voluminous variety of commercially available data. If the data is generally available, customers may be using it as well.

Another option is to program computers to ignore commercially sensitive information that, although publicly available, is of little or no value to customers but helps the competitors arrive at a supracompetitive price. ${ }^{121}$ Identifying such information, however, is problematic. Part of the value of big data is data fusion, whereby computers link data sets from which new insights emerge. ${ }^{122}$ Moreover, the data for some applications - such as customers sharing their inventory data with suppliers - can promote efficiency while raising antitrust concerns. ${ }^{123}$ Even if the customers limit what information can be shared, the algorithms-by analyzing a variety of data-could fill in the gaps. So it would likely be

120. OECD, supra note 103 , at 12 . Why would competitors share a future price increase among themselves exclusively (or before announcing it publicly)? One possibility is to avoid the risk of losing customers as they negotiate through successive communications about how much to increase prices (or to decrease them, to threaten discounters). Moreover, by voluntarily sharing detailed transactional information with each other, the competitors can effectively police the price increase and detect any cheating. The customers, on the other hand, stand little, if anything, to gain by this increased price transparency among competitors. They are still largely in the dark about the future price increase (and thus cannot effectively adjust their purchases) or the prices that others have paid (and thus cannot leverage a better price with this information). It is questionable then how the marketplace is rendered more efficient and competitive by such asymmetric exchanges.

121. As an example, in Petroleum Products, the defendant oil companies publicly announced, at times in advance of the effective date, the discounts (or decisions to withdraw discounts) to their franchisee gasoline stations. In re Coordinated Pretrial Proceedings in Petroleum Products Antitrust Litig., 906 F.2d 432, 445 (9th Cir. 1990). The public dissemination of the discount information was of little value to the defendants' franchisees or the end consumer. The franchisees could not shop around for the best oil prices: they could only purchase from their franchisor. Nor did the consumers care what the gas station paid for the gasoline. They cared only about the retail price. The purpose and effect then of publicly announcing changes in discounts to the franchisees were, as several defendants' executives admitted, to quickly inform their competitors of the price change in the express hope that these competitors would follow the move and restore their prices. Without such transparency, the other defendants might not have readily detected one defendant's withdrawal of its discount and followed accordingly because the individual branded gas stations' retail prices varied considerably.

122. Maurice E. STUCKe \& Allen P. Grunes, Big Data and Competition Policy 21-22 (Oxford University Press 2016); EXecutive OfFICE OF THE PREsIdent: PREsIdent's CounCIL OF AdVisors ON SCIENCE AND TEChNOlogy, Big Data AND PRIVACY: A Technological PERSPECTIVE X (2014); ORganisation FOR ECONOMIC CO-OPERATION AND DEVELOPMENT, SuPPORTING INVESTMENT IN KNOWLEDGE CAPITAL, GROWTH AND INNOVATION 325 (2013) ("In some cases, big data is defined by the capacity to analyse a variety of mostly unstructured data sets from sources as diverse as web logs, social media, mobile communications, sensors and financial transactions. This requires the capability to link data sets; this can be essential as information is highly context-dependent and may not be of value out of the right context. It also requires the capability to extract information from unstructured data, i.e., data that lack a predefined (explicit or implicit) model.").

123. Stan. GSB Staff, Sharing Information to Boost the Bottom Line, STAN. BUS. (Mar. 1, 1999), https:/www.gsb.stanford.edu/insights/sharing-information-boost-bottom-line. 
difficult to program the computers to ignore data sets without reducing efficiency.

\section{Injecting Uncertainty in a Certain World}

One enemy of collusion is the maverick firm, which "plays a disruptive role in the market to the bencfit of customers." ${ }^{24}$ A maverick may offer a disruptive technology or business model, take the lead in cutting prices (or resisting its rivals' attempts to raise price), or expand its production capacity. ${ }^{125}$ Consequently, mavericks can program their pricing algorithm to behave as a maverick, such as rewarding market share growth over profitability within certain bounds, so as to enable them to quickly expand..$^{126}$

But even here, the rival firms' computers may develop counterstrategies that ultimatcly thwart market share growth and foster instead coordinated behavior. Moreover, in industries where competitors compete in multiple product and geographic markets, computers can learn to retaliate across markets (e.g., the incumbent offers a steep discount in the maverick's home market or markets sheltered from competition), which the mavcrick's pricing algorithm can quickly learn is correlated with its discounting, thereby reducing its incentive to discount. ${ }^{127}$

Another possibility is for the government to promote entry by mavericks with different incentives. One example would be entry by consumer-owned cooperatives, where the supra-competitive profits are redistributed to consumers (in the form of rebates). The rebate could effectively return prices to their competitive levels. One risk, however, is that cooperatives, subject to weak corporate governance, dissipate the profits on internal salaries, perks, or expansion into other markets.

\section{Reconsidering the Relationship Between Humans and Machines}

The Digital Eye scenario raises ethical and policy questions on the relationship between humans and machines. In such instances, can the law attribute liability to companies for their computers' actions? At what stage, if any, would the designer or operator relinquish responsibility over the acts of the machine?

Evidently, defining a benchmark for illegality in such cases is challenging. It requires close consideration of the relevant algorithm to establish whether any illegal action could have been anticipated or was predetermined. Such review requires consideration of the programming of the machine, available safeguards, its reward structure, and the scope of its activities. The ability to identify the strand which is of direct relevance is questionable. The complexity of the algorithms' data-processing

124. 2010 Merger Guidelines, supra note 75, \$ 2.1.5.

125. See id.

126. See id.

127. See id. 
and self-learning increases the risk that enforcers, in undertaking this daunting undertaking, stray far afield of rule of law ideals, such as transparency, objectivity, predictability, and accuracy.

Further, one must consider the extent to which humans may truly control self-learning machines. Humans design the initial algorithm, determine to launch it, and, arguably, could shut the computer down. But between its creation and death, the computer can undertake many strategies. Could a self-learning machine choose strategies that indirectly circumvent safeguards imposed to protect consumer welfare and operate independently to maximize profit? Could machines simply override the safeguards? Such questions draw attention to wider ethical and moral issues, which may affect the way our society evolves, and our ability to control and restrict such developments. ${ }^{128}$

In the context of competition and markets, friction among profit maximization, ethical trading, and consumer welfare exists. As algorithms, through reinforcement learning, identify ingenious solutions, consumers and society can benefit. But as algorithms extend to everyday business decisions, such as fixing the prices for goods and services, there is also the possibility that computers-to maximize profits-engage in coordinated, accommodating, or interdependent behavior. Importantly, they may do so through self-learning and rational decision-making, in a deterrent-free environment, bypassing safeguards which inhibit traditional price fixing or collusion. ${ }^{129}$

To illustrate the multiple ethical decisions "smart" computers may have to make, consider the design of smart, "autonomous" cars. In designing these cars, car makers have to consider whether algorithms should replicate ethical human decision-making. ${ }^{130}$ Such may be the case, for instance, when the computer identifies an imminent crash and needs to consider evasive action. Alternative crash outcomes may include, for example, severely injuring a child, killing an old person, or damaging property. The ethical decision as to the least harmful action cannot be taken lightly. ${ }^{131}$

By analogy from the machine ethics debate, one may pose the question as to how one could integrate ethics and legality into a computer

128. Nick Bostrom, Superintelligence: Paths, Dangers, Strategies 217-20 (2014); WENDEll Wallach \& COLIN Allen, MORAl MaChines: TEACHING RoBots Right From WRONG 6 (2009); See IsAaC Asimov, I, RoBot (4th ed., 2008); Samir Chopra \& Laurence White, Artificial Agents-Personhood in Law and Philosophy, in PROCEEDINGS OF THE 16th EUR. CONF. ON ARTIFICIAL INTELLIGENCE 635 (2004); Colin Allen, Iva Smit \& Wendell Wallach, Artificial Morality: Top-Down, Bottom-Up, and Hybrid Approaches, 7 ETHICs \& INFO. TECH. 149 (2005); James H. Moor, The Nature, Importance and Difficulty of Machine Ethics, 21 INTELLIGENT SYSTEMS, IEEE 18 (2006); Michael Anderson \& Susan Leigh Anderson, Machine Ethics: Creating an Ethical Intelligent Agent, 28 AI MAG. 15 (2007).

129. See Eur. Res. Council, Self-Learning Ai Emulates the Human Brain (2016), https://erc.europa.eu/projects-figures/stories/self-learning-ai-emulates-human-brain.

130. See Chris Bryant, Driverless Cars Must Learn to Take Ethical Route, FIN. Times (Mar. 1, 2015, 3:27 PM), https://www.ft.com/content/4ab2cc1e-b752-11e4-981d-00144feab7de?mhq5j=e4.

131. See id. 
program. ${ }^{132}$ Outside the clear instance of collusion through communications, how could one constrain the computer's actions to avoid anticompetitive outcomes? Should such a move focus on the competitiveness of the market as a limiting benchmark or rather on illegality? As the two do not necessarily overlap, an explicit prohibition may not resolve the problem. Our concern stems from the ability of the machine to change the competitive landscape and thus reduce competition.

In the area of ethics and morality, a rule-based approach to AI has been criticized for its unsuitability and has proven to be insufficiently robust for most real-world tasks. ${ }^{133}$ When considered in the context of facilitating tacit collusion, one may wonder whether it may provide any workable rules to follow.

This brings us back to the legal question of liability. To what extent should or could liability be imputed on the creator or opcrator of the machine? Should the human and machines be viewed as independent or rather be treated as one? For instance, when should the law attribute liability to companies for their computers' actions? The answer is easy when humans design and program the algorithm to further their illegal scheme. The answer is harder when a human command did not direct the computer's actions. Instead, the computer's action is the outcome of many intermediate steps of computer learning, which evolved from evaluating a voluminous variety of data. Thus, tacit collusion was not reasonably foreseeable as the likely and natural consequence. Granted, on one level, the firm is accountable: it created, used, and profited from the algorithm. But at what point, if any, would the designer or operator relinquish responsibility over the acts of the machine? If companies face strict liability for their computer's tacit collusion, how could they constrain their computer's actions to avoid less competitive outcomes? In instances in which the machine does not directly act on the designer's or operator's specific instructions, can liability be imputed? Can the use of a selflearning machine be condemned?

\section{E. Deterrence and Liability}

When considering liability in scenarios involving algorithms, it is helpful to distinguish between the initiation and implementation phases. When collaboration or communication dominate the initiation (human) phase, lack of it in the implementation (computerized) phase should not serve to evade liability. The full life cycle of the collusion should be considered. Otherwise, a selective view of implementation which does not take account of earlier communication or signaling may provide for a false negative and fail to consider the market dynamics in context.

When no such communications are present at the initiation and implementation stages, the question of liability becomes more complicated.

132. See EUR. RES. COUNCIL, supra note 129.

133. Allen, Smit \& Wallach, supra note 128, at 149-50. 
A possible solution may concern the imposition of liability once defendants become aware of the coordinated, accommodating behavior among the rivals' computers. Such approach has been adopted in other legal areas, whereby one is liable for continuing to knowingly benefit from an illegal source of income. For example, in the UK, there is liability under the Proceeds of Crime Act 2002 for dealing with funds that one suspects of being criminal property, even if the defendant was not involved in the creation of those funds in the first place. ${ }^{134}$

But would such an approach provide a workable intervention principle? Suppose the company recognizes that its computerized pricing structure is optimizing profits. It is plausible that profits are increasing as the computer programs are reducing costs (such as better utilizing resources) or using price discrimination and strategic discounting. It would be unlikely for the company to ascertain precisely to what extent the increase in profits is attributable to coordinated, accommodating, or interdependent behavior. It may be impossible to determine the extent to which the computer is reacting to market dynamics or shaping them. Would a hunch by executives that some profits are coming from tacit collusion be enough to impose antitrust liability?

In addition, if the defendants become aware of tacit collusion, what can they do about it? Depending how far the pricing mechanism is integrated with other functions, they could not necessarily turn off the computer. Nor could they necessarily override the algorithm's price with their own price, as it may be logistically impossible to enter and update the pricing across markets. Moreover, the adjusted pricing may still be inflated.

Assuming that the computers are programmed to refrain from any violation of the competition laws, the company may have done all it can to ensure compliance. The facilitation of conscious parallelism through rational, independent action may well fall outside compliance with competition law. Furthermore, programming compliance is challenging, particularly when one attempts to capture the creation of a market dynamic like conscious parallelism. A command not to fix price may be simple to execute; but, under reinforcement learning, the algorithm will seek ingenious solutions including, as the competition authorities recognize, the myriad possibilities of coordinated interaction, not all of which are illegal..$^{135}$

\section{F. Incremental Changes}

Another conceptual difficulty concerns the benchmark one may use to establish the counterfactuals when dealing with the creation or strengthening of tacit collusion.

134. Proceeds of Crimes Act 2002, c. 29, § 340 (Eng.).

135. On this point, see 2010 Merger Guidelines, supra note 75 , $§ 7$. 
Today, we may benefit from market transparency, which was unavailable before the Internet era. This transparency, and modern speed of communications can, however, under certain market conditions, also lead to tacit collusion and supra-competitive prices. Yet, we do not suggest to treat this advance in technology as the focal point for antitrust investigation. In fact, we treat the current level of transparency as a direct outcome of market dynamics.

Computer programs and algorithms are constantly changing and improving in their ability to optimize decision-making. Similarly, the interface between humans and computers is rapidly evolving. As market transparency and interdependence are subjected to incremental changes-how does one identify credible counterfactuals when assessing changes in market dynamics? Should the last incremental development be contrasted with the previous one or with a computer-free reality? Absent a transformative change in technology and market dynamics, it may be difficult to identify the point of intervention and comparison. After all, today's artificial levels of transparency may be tomorrow's acceptable norm.

The shifting norms also reflect the regulatory challenges if the government altered the speed for price changes. Suppose, for example, the government regulated firms' pricing algorithms to slow down pricing changes across the entire system. The pricing algorithms, while continually monitoring the rivals' pricing and business maneuvers, would now face a time delay in changing price. Under this scenario, the maverick -if the delay were long enough-could profit from being the first to lower its price. But this solution faces political problems: competitors would quickly complain that the government is preventing them from discounting.

One alternative is if the government allowed price decreases to be immediately implemented, but imposed a time lag for price increases. But pricing algorithms, like humans, could game the system. For example, a dominant incumbent could punish the maverick by undercutting its price. The maverick could not immediately raise its price, and would be forced to lower its price even further. Taking this into account, the maverick's algorithm, before discounting, would likely calculate the probability of incumbents retaliating, its costs (including lost profits) in discounting, and the benefits (which would be slight if rivals would instantly match the maverick's lower price). The governmental pricing delayrather than help the maverick and consumers-would instead serve as a punishment mechanism for defecting from the supra-competitive price. In reducing the maverick's incentives to lower price in cases where retaliation is likely, the governmental pricing delay would unintentionally fos- 
ter tacit collusion. We explore elsewhere other potential countermeasures to tacit algorithmic collusion. ${ }^{136}$

\section{G. Active Intervention}

Considering the above, it may be challenging for law-makers to identify (and enforce) a clear, enforceable triggering event for intervention that would prevent the anticompetitive market dynamics.

At the legislative level, one could consider an ex ante approach by which, under certain market conditions, companies must report the use of certain algorithms. Such a regulatory mechanism is likely to impose costs at agency and company levels. It may also prove difficult to implement, especially in cases involving Category IV. Competition authorities would have a difficult time overseeing firms' attempts to design a machine to optimize performance while instructing it to ignore or respond irrationally to market information and competitors' moves, or to pursue inefficient outcomes.

An ex post approach may trigger intervention when markets seem to operate in concert. A market investigation or inquiry, initiated by the competition agency, may provide an effective ex-post vehicle to consider the functioning of certain markets. Take, for example, the powers of the UK Competition and Markets Authority to initiate market investigations, gather and appraise evidence, and, where neccssary, impose structural or behavioral remedies. ${ }^{137}$ Other authorities possess similar, albeit more limited powers, to investigate sectors of the economy, publish reports, and initiate action. ${ }^{138}$ In the context of this Article, such powers may be used to evaluate computerized market environments, and require companies to reveal the nature of algorithms used in an attempt to ascertain whether these algorithms create excessive transparency or lead to interdependence. The more selective intervention under an ex post regime may have more limited cost implications. It may also limit the possible adverse effects on innovation and investment, as it is only after tacit collusion is detected that the market is subjected to a monitoring exercise. An ex post monitoring exercise would require the legislator to determine whether liability ought to be imputed on the companies involved. Taking our earlier discussion into account, onc may favor a no liability rule (Category IV) absent clear evidence of intent (Category III).

136. Ariel Ezrachi \& Maurice E. Stucke, Algorithmic Collusion: Problems and Counter-Measures (Organisation for Economic Co-operation and Development, Note, 2017), http://www.oecd.org/ officialdocuments/publicdisplaydocumentpdf/?cote $=\mathrm{DAF} / \mathrm{COMP} / \mathrm{WD}(2017) 25 \& \mathrm{docL}$ anguage $=\mathrm{En}$.

137. COMPETITION COMMISSION, Guidelines FOR MARKET INVESTIGATIONS: TIIEIR ROLE, PROCEDURES, ASSESSMENT AND REMEDIES, CC3 (REVISED) (Apr. 2013), https:/www.gov.uk/ government/uploads/system/uploads/attachment_data/file/284390/cc3_revised.pdf. Adopted by the CMA Board

138. See for example the European Commission's power to carry out Sector inquiries pursuant to Article 17 of Regulation 1/2003. Noteworthy is the Commission's Sector inquiry into e-commerce in the EU, launched on 6 May 2015. The Commission published its final report in 2017. 
Another intervention is price regulation. F.A. Hayek in the 1940s accurately identified the knowledge problem confronting any price regulator:

[T] he "data" from which the economic calculus starts are never for the whole society "given" to a single mind which could work out the implications and can never be so given. The peculiar character of the problem of a rational economic order is determined precisely by the fact that the knowledge of the circumstances of which we must make use never exists in concentrated or integrated form but solely as the dispersed bits of incomplete and frequently contradictory knowledge which all the separate individuals possess. ${ }^{139}$

But we are moving from an analog to digital world, where firms can use Big Data and Big Analytics to better predict an individual's reservation price and preferences. ${ }^{140}$ If firms can harness Big Data and Big Analytics to determine the profit-maximizing collusive price (or ways to price discriminate perfectly), can the government use pricing algorithms to determine a competitive price? As Hayek recognized, "[i]f we possess all the relevant information, if we can start out from a given system of preferences, and if we command complete knowledge of available means, the problem which remains is purely one of logic."114 So one could argue that price regulation in the post-Hayekian world of Big Data is possible once industry data on individual consumer preferences and firm costs is collected and analyzed. If Uber, as an intermediary, can calculate the surcharge for its many drivers and passengers during periods of congestion, then one may ask why the government couldn't use pricing algorithms to monitor and update industry. One set of concerns involves incentives and regulatory capture. Moreover, the road to perfect price regulation may also lead to a world of limited privacy, among other things. ${ }^{142}$

Consequently, under current law, competition agencies may find it difficult to challenge each firm's unilateral decision to use sophisticated algorithms to analyze market information and determine prices, even if it results in higher prices to the detriment of consumers. Be it an ex post or ex ante regime, one has to confront the challenge of identifying the adequate level of intervention, if such exists, when dealing with the creation of market conditions for conscious parallelism. A remedy which requires an algorithm to ignore market prices or not to react to market changes may well undermine competition. The enforcer's efforts to reduce price transparency may similarly harm consumers. Undoubtedly, intervention would require careful technological and policy finc tuning to avoid these pitfalls. Some may argue that these challenges should even tilt the bal-

139. Friedrich A. Hayek, The Use of Knowledge in Society, 4 AM. ECON. REv. 519, H.3 (1945), http://www.econlib.org/library/Essays/hykKnw1.html.

140. How Companies Are Using Big Data and Analytics, MCKINSEY \& Co., http://www. mckinsey.com/business-functions/mckinsey-analytics/our-insights/how-companies-are-using-big-dataand-analytics (last visited Aug. 9, 2017).

141. Hayek, supra note 139, at H.1.

142. See EZRACHI \& STUCKE, supra note 67 
ance in favor of nonintervention. Such an approach, however, risks creating a lacuna which market players may exploit. Assuming that technology can provide benchmarks and tools for intervention, enforcers should not simply ignore algorithmic tacit collusion.

\section{CONCLUSION}

Computer algorithms have transformed the way we trade and will continue to do so in an increasing pace. The creation of fast-moving, digitalized markets yields many benefits, yet algorithms also change the dynamics of competition, and may limit it.

Our discussion explored four categories of algorithmic-supported collusion. ${ }^{143}$ We identify as most challenging, from both legal and enforcement perspectives, instances in which algorithms facilitate conscious parallelism and are not likely to be challenged under current laws.

Category IV, which concerns the use of autonomous machines, further challenges our thinking as it raises questions as to the relationship between humans and machines. These questions may become increasingly prominent as technology advances and AI becomes an integral part of our surroundings.

The possible detachment between the actions of the algorithm and its human designers and operators raises challenges regarding the ability to attribute liability to its operators, who may escape scrutiny due to the unforeseen nature of self-learning. Rule of law concerns include how to differentiate between express agreement and accommodating behavior, and greater subjectivity over whether and when computers "agreed." Ethical concerns include to what extent should humans be held accountable for low probability or hard to predict events? With no human intent and immoral conduct, there is a greater risk of jury nullification.

The detachment between the algorithm and its operators also reveals a potential failure to deter as algorithms are not susceptible to traditional deterrents, such as jail, monetary fines, and shaming.

In a digitalized universe in which the law's moral fabric is inapplicable, game theories will be constantly modelled until a rational, predicable outcome is identified. Given the transparent nature of these markets, algorithms may change the market dynamics and facilitate tacit collusion, higher prices, and greater wealth inequality. In such a reality, firms may have a distinct incentive to shift pricing decisions from humans to algorithms. Humans will more likely wash themselves of any moral concerns, in denying any relationship and responsibilities between them and the computer.

143. See supra Part III. 
So, it is noteworthy that we enter this new antitrust world with a small-stakes case like Topkins. ${ }^{144}$ The companies used algorithm-based pricing software to sell their posters, prints, and framed art online. But the executives still had one foot in the old cartel world as they allegedly discussed and agreed among themselves to fix prices for their products. ${ }^{145}$ How will competition officials respond when the executives leave this old world behind? When the executives no longer need to meet in hotel rooms since their pricing algorithms, in enhancing market transparency, foster classic tacit collusion and new forms of anticompetitive conduct? How will the agencies and courts respond to this new world of collusion? This remains unclear. Policy-makers must recognize the dwindling relevance of traditional antitrust concepts of "agreement" and "intent" in the age of Big Data and Big Analytics. Rather than redefining agreement or intent, perhaps policy-makers need to introduce checks and balances to lessen the risks of algorithmic tacit collusion.

144. Press Release, Dep't of Justice, Former E-Commerce Executive Charged with Price Fixing in the Antitrust Division's First Online Marketplace Prosecution (Apr. 6, 2015), http://www.justice. gov/atr/public/press_releases/2015/313011.docx.

145. Id. 
